\title{
Pengaruh Working Capital Management terhadap Kinerja dan Risiko Perusahaan
}

\author{
Wita Juwita Ermawati \\ Departemen Manajemen, Fakultas Ekonomi dan Manajemen \\ Institut Pertanian Bogor \\ Kampus Darmaga Bogor 16680 \\ Email: wiet_07@yahoo.com
}

\begin{abstract}
It is important to manage and optimized working capital properly due its performance, risk implication and share value to the company. The tradeoff between profitability and liquidity determine the behavior of aggressiveness level of capital management of the company. Therefore, these study objectives are to identify the impact of cash conversion cycle on corporate financial performance and risk, and to identify the impact of aggressiveness level of capital management on corporate financial performance and risk. The study is focusing on 14 manufacture companies listed on Indonesian Stock Exchange. The study showed different result, which the cash conversion cycle was not significantly affecting corporate financial performance and risk; meanwhile the aggressiveness level of capital management was significantly affecting corporate financial performance and risk. Many of hypotheses were not able showed expected result due of limitation of sampling and short observation period or caused by the differences between companies in types, number of assets, liabilities, sales and credit policies.

Key words: working capital management, cash conversion cycle, financial performance, risk

\section{Pendahuluan}

Working capital management atau manajemen modal kerja sangat penting untuk diperhatikan oleh setiap perusahaan karena perusahaan harus mengelola aset lancar dan kewajiban lancarnya dengan baik. Working capital management akan memengaruhi likuiditas dan profitabilitas, padahal selalu terdapat trade off antara likuiditas dan profitabilitas. Jika perusahaan tidak memperhatikan profitabilitas, perusahaan tidak akan dapat bertahan untuk waktu yang lama. Tetapi jika tidak memerhatikan likuiditas, perusahaan akan menghadapi masalah insolvency atau kebangkrutan. Oleh karena itu working capital management harus diperhatikan oleh setiap perusahaan (Raheman dan Nasr, 2007).

Aset lancar sangat penting untuk diperhatikan karena erat kaitannya dengan likuiditas perusahaan. Komposisi aset lancar perusahaan pada umumnya sangat besar, dapat mencapai setengah dari total aset perusahaan (Deloof dalam Mathuva, 2010). Akan tetapi tingkat aset lancar yang tinggi dapat menghasilkan return on investment di bawah standar yang diinginkan. Di lain pihak, perusahaan dengan aset lancar yang
\end{abstract}


rendah akan mengalami kekurangan dan kesulitan dalam operasionalisasi usahanya (Van Horne dan Wachowicz dalam Mathuva, 2010). Oleh karena itu, perusahaan perlu mempertahankan aset lancarnya pada tingkat yang optimal.

Literatur mengenai corporate finance yang tradisional memfokuskan studinya pada keputusan pendanaan jangka panjang, khususnya adalah terkait dengan investasi, struktur modal, dividen, dan keputusan penilaian perusahaan. Padahal aset jangka pendek dan kewajiban jangka pendek merupakan komponen penting yang perlu dianalisis secara saksama. Pengelolaan aset dan kewajiban jangka pendek ini perlu diperhatikan secara hati-hati karena working capital management memiliki peran yang penting dalam profitabilitas dan risiko perusahaan dan juga nilai perusahaan (Smith dalam Nazir dan Afza, 2009). Hal tersebut juga diperkuat oleh Zariyawati, et al (2009) yang menyebutkan bahwa working capital sering diabaikan dalam pengambilan keputusan keuangan karena hanya melibatkan investasi dan pendanaan dalam jangka pendek. Padahal working capital merupakan komponen yang penting dalam keputusan manajemen keuangan perusahaan. Working capital management yang optimal diharapkan dapat memberikan kontribusi yang positif terhadap penciptaan nilai perusahaan. Untuk mendapatkan working capital management yang optimal, manajer perusahaan harus mengendalikan trade off antara profitabilitas dan likuiditas secara akurat.

Tujuan working capital management adalah mengelola akun lancar perusahaan sehingga dapat mencapai keseimbangan antara profitabilitas dan risiko (Ricci dan Vito, dalam Mathuva, 2010). Dong dan Su (2010) juga menyebutkan hal yang sama, bahwa tujuan mendasar dari working capital management adalah mengelola aset lancar dan kewajiban lancar perusahaan. Dengan kata lain, working capital harus dipertahankan pada tingkat yang sesuai, tidak terlalu tinggi ataupun terlalu rendah. Oleh karena itu perusahaan harus mengefisiensikan pengelolaan working capital-nya. Working capital management yang efisien merupakan komponen integral dari strategi perusahaan keseluruhan untuk menciptakan nilai bagi pemegang saham (Shin dan Soenen dalam Dong dan Su, 2010). Sedangkan menurut Eljelly dalam Mathuva (2010), working capital management yang efisien melibatkan perencanaan dan pengendalian aset lancar dan kewajiban lancar dalam rangka mengurangi risiko ketidakmampuan perusahaan untuk memenuhi kewajiban jangka pendeknya dan untuk mengurangi kelebihan investasi dalam aset ini.

Komponen working capital management (WCM) meliputi average collection period (ACP), inventory conversion period (ICP), average payment period (APP), dan cash conversion cycle (CCC). Selain itu, working capital management juga dapat dilihat dan diukur dari tingkat keagresifan perusahaan dalam menerapkan kebijakan working capital management-nya. Perusahaan yang agresif atau konservatif dalam kebijakan working capital-nya akan menghasilkan kinerja yang berbeda dan menghadapi risiko yang berbeda pula. Mayoritas penelitian sebelumnya menunjukkan bahwa cash conversion cycle, average collection period, dan inventory conversion period berpengaruh negatif terhadap kinerja perusahaan, sedangkan average payment period berpengaruh positif terhadap kinerja perusahaan (Dong dan Su, 2010; Mathuva, 2010; Raheman dan Nasr, 2007; Sen dan Oruc, 2009). Terkait dengan tingkat agresivitas kebijakan working capital management, Weinraub dan Visscher (1998) menyebutkan 
bahwa kebijakan working capital asset (investasi) yang agresif akan diikuti dengan kebijakan working capital financing (pendanaan) yang konservatif. Sedangkan Horne dan Wachwicz dalam Nazir dan Afza (2009) menyebutkan bahwa kebijakan investasi yang konservatif akan memiliki pengaruh negatif terhadap profitabilitas perusahaan. Dengan kata lain, kebijakan investasi yang agresif akan memiliki pengaruh positif terhadap profitabilitas perusahaan.

Profitabilitas perusahaan juga akan diikuti dengan risiko yang mungkin terjadi. Jika profitabilitas tinggi maka risikonya juga tinggi, begitu juga sebaliknya. Keputusan perusahaan untuk cenderung memaksimalkan profitabilitas (dan menerima risiko yang tinggi) akan cenderung menurunkan tingkat likuiditas perusahaan. Sebaliknya, perusahaan yang cenderung lebih memaksimalkan likuiditas perusahaan akan menurunkan potensi profitabilitas perusahaan (Deloof et al dalam Mathura 2008). Hal ini terjadi karena jika perusahaan ingin memaksimalkan profitabilitas, maka akan mengurangi aset lancar (karena aset lancar menghasilkan tingkat pengembalian yang rendah) dan meningkatkan aset tetap (karena aset tetap memberikan tingkat pengembalian yang tinggi), tetapi konsekuensinya adalah likuiditasnya menjadi rendah. Sebaliknya, jika perusahaan ingin memaksimalkan likuiditas maka akan meningkatkan aset lancar, tetapi tingkat pengembaliannya akan rendah sehingga profitabilitas juga rendah. Tetapi menurut Zariyawati, et al (2009); Mathuva (2010); Gill, et al (2010), jika perusahaan dapat memiliki penjualan yang lebih besar dengan kebijakan kredit yang lunak, hal ini dapat memperpanjang siklus kas. Dengan demikian, semakin panjang cash conversion cycle, profitabilitas akan menjadi semakin tinggi. Hal ini berlawanan dengan pandangan tradisional yang menyebutkan bahwa semakin panjang conversion cycle maka profitabilitas akan semakin rendah.

Dengan melihat pentingnya working capital management dalam perusahaan serta adanya perbedaan temuan penelitian terdahulu mengenai pengaruh working capital management (cash conversion cycle) terhadap kinerja perusahaan (profitabilitas), penulis merasa perlu untuk menguji pengaruh working capital management terhadap kinerja perusahaan-perusahaan di Indonesia dan juga risikonya. Selain itu juga perlu diuji apakah tingkat keagresifan dalam kebijakan working capital management dapat berdampak pada perbedaan kinerja dan risiko yang dihadapi perusahaan.

Oleh karena itu terdapat rumusan masalah yang diangkat pada penelitian ini dengan melihat working capital management berdasarkan komponen-komponennya sebagai berikut :

1. Apakah komponen working capital management (ACP, ICP, APP, CCC) mempengaruhi kinerja dan risiko perusahaan ?

2. Apakah tingkat keagresifan working capital management mempengaruhi kinerja dan risiko perusahaan?

Komponen working capital management utama yang diuji pada penelitian ini adalah cash conversion cycle. Oleh karena itu berdasarkan rumusan masalah yang diajukan, tujuan dari penelitian ini adalah sebagai berikut :

1. Menguji pengaruh cash conversion cycle terhadap kinerja perusahaan.

2. Menguji pengaruh tingkat keagresifan working capital management terhadap kinerja perusahaan.

3. Menguji pengaruh cash conversion cycle terhadap risiko perusahaan. 
4. Menguji pengaruh tingkat keagresifan working capital management terhadap risiko perusahaan.

\section{Metode Penelitian}

Untuk memaksimalkan kesejahteraan pemegang saham, terdapat tiga keputusan keuangan yang harus dibuat, yaitu keputusan investasi, keputusan pendanaan, dan keputusan modal kerja. Keputusan modal kerja (working capital) tidak menunjukkan pengaruh langsung terhadap pertambahan nilai, tetapi tingkat kepentingannya sama dengan keputusan investasi dan keputusan pendanaan. Dalam kebijakan working capital terdapat trade off antara risiko dan profitabilitas (kinerja). Working capital pada aset lancar umumnya mempunyai tingkat keuntungan yang lebih rendah dibandingkan dengan investasi pada aset tetap. Karena itu working capital yang kecil (investasi pada aset lancar yang rendah) akan lebih menguntungkan perusahaan (kinerja meningkat). Tetapi working capital yang kecil akan menaikkan risiko perusahaan, khususnya risiko likuiditas. Working capital management juga dapat dilihat dan diukur dari tingkat keagresifan perusahaan dalam menerapkan kebijakan pengelolaan modal kerjanya. Perusahaan yang agresif atau konservatif dalam kebijakan modal kerjanya akan menghasilkan kinerja yang berbeda dan menghadapi risiko yang berbeda pula.

Penelitian ini menguji tiga issue, yaitu working capital management (WCM), kinerja perusahaan, dan risiko perusahaan. Working capital management dibedakan juga berdasarkan tingkat aggresivitasnya. Proxy yang digunakan untuk mengukur working capital management terdiri dari beberapa ukuran, yaitu cash conversion cycle (CCC yaitu perputaran kas dari mulai kas dikeluarkan sampai kas diterima kembali), average collection period (ACP, yaitu waktu yang dibutuhkan untuk mengumpulkan kas dari konsumen), inventory conversion period (ICP, yaitu waktu yang dibutuhkan untuk mengubah persediaan menjadi penjualan) dan average payment period (APP yaitu waktu yang dibutuhkan untuk membayar kewajiban kepada kreditor atau supplier). Sedangkan ukuran yang menunjukkan tingkat keagresifan working capital management yaitu aggressive investing policy (AIP, yang dapat dihitung sebagai rasio current asset dibandingkan dengan total asset) dan aggressive financing policy (AFP, yang dapat dihitung sebagai rasio current liabilities dibandingkan dengan total asset). Dua pengukuran kinerja perusahaan pada penelitian ini berfokus pada tingkat profitabilitas perusahaan yang diukur dengan ukuran akuntansi yaitu return on asset (ROA yaitu tingkat pengembalian yang didapat perusahaan dibandingkan dengan total aset yang dimilikinya). Sedangkan pengukuran risiko perusahaan menggunakan proxy standar deviasi dari return on asset (SDROA). Terdapat beberapa penelitian mengenai working capital management yang telah dilakukan di beberapa negara, diantaranya yaitu Belgia, Yunani, Mauritius, Pakistan, Malaysia, Vietnam, Kenya, dan Amerika Serikat. Hasil temuan dari penelitian-penelitian tersebut tidak sepenuhnya konsisten. Oleh karena itu penelitian ini ingin menguji pengaruh working capital management (khususnya adalah cash conversion cycle) terhadap kinerja dan risiko perusahaan untuk kasus di Indonesia dengan mengambil sampel 14 perusahaan manufaktur yang terdaftar di Bursa Efek Indonesia. Kerangka pemikiran secara lebih jelas dapat dilihat pada Gambar 1. 


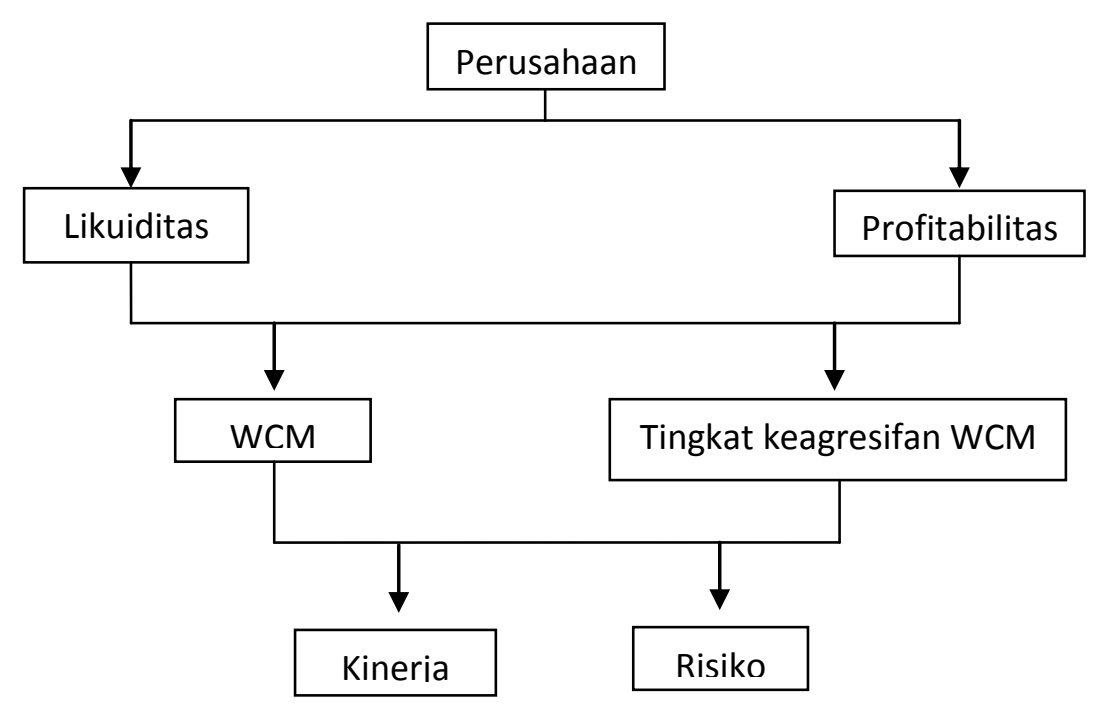

Gambar 1. Kerangka Pemikiran Penelitian

Penelitian ini merupakan penelitian kuantitatif yang menggunakan data sekunder dengan sampel perusahaan sebanyak 14 perusahaan manufaktur yang terdaftar di Bursa Efek Indonesia.

Data yang digunakan pada penelitian ini adalah data sekunder yang merupakan data-data keuangan dari tahun 2008 - 2010 untuk 14 perusahaan yang terdaftar di Bursa Efek Indonesia (BEI). Data-data laporan keuangan yang dibutuhkan meliputi total asset, current asset, fixed asset, accounts receivables, inventory, total liabilities, shortterm loans, long-term loans, accounts payables, sales, cost of sales, purchases, net earning after tax, dan umur perusahaan. Data-data tersebut diperoleh dari database Bursa Efek Indonesia (BEI). Selain itu juga data pertumbuhan Gross Domestic Product (GDP) dalam nominal yang didapat dari database Badan Pusat Statistik (BPS). Sampel perusahaan dipilih menggunakan metode purposive sampling, yaitu perusahaan agroindustri atau perusahaan manufaktur yang menghasilkan produk yang terkait dengan bidang pertanian dalam arti luas.

Berdasarkan penelitian-penelitian sebelumnya yang dilakukan di beberapa negara, pada penelitian ini dirumuskan 4 hipotesis sebagai berikut :

$\mathrm{H} 1$ : Cash conversion cycle memengaruhi kinerja perusahaan secara negatif.

$\mathrm{H} 2$ : Tingkat keagresifan working capital management memengaruhi kinerja perusahaan secara positif.

H3: Cash conversion cycle mempengaruhi risiko perusahaan secara negatif.

$\mathrm{H} 4$ : Tingkat keagresifan working capital management memengaruhi risiko perusahaan secara positif.

Berdasarkan empat hipotesis tersebut, beberapa pengujian dilakukan untuk menguji hipotesis tersebut dengan menggunakan software Eviews. Pengujian Pengaruh Cash Conversion Cycle terhadap Kinerja Perusahaan yaitu Variabel dependen untuk pengujian ini adalah kinerja perusahaan yang di-proxy-kan oleh return on asset (ROA). Variabel independen utama yang digunakan pada pengujian ini adalah cash conversion cycle (CCC). Namun demikian terdapat variabel independen lain yang juga 
diuji yaitu variabel average collection period (ACP), inventory conversion period (ICP), dan average payment period (APP). Hal ini dilakukan untuk mengetahui variabel mana dari komponen WCM tersebut yang memberikan pengaruh lebih besar atau paling dominan terhadap kinerja perusahaan. Dengan demikian variabel dependen yang dihipotesiskan hanya cash conversion cycle, karena CCC melibatkan variabel ACP, ICP, dan APP dalam perhitungannya.

Pada pengujian ini terdapat variabel kontrol yang digunakan yaitu firm size (FS), debt ratio (debt), fixed asset ratio (FAR), gross domestic product growth (GDPGrow), umur perusahaan (Age).

Pengukuran variabel-variabel yang digunakan pada pengujian ini adalah sebagai berikut :

- Return on Asset (ROA) = Net earning after tax (NEAT) Total assets (TA)

- Average Collection Period $(\mathrm{ACP})=\underline{\text { Accounts receivables }} \times 365$

$$
\text { Sales }
$$

- Inventory Conversion Period $(\mathrm{ICP})=$ Inventory $\times 365$

$$
\text { Cost of sales }
$$

- Average Payment Period (APP) $=\underline{\text { Accounts payables }} \times 365$

$$
\text { Purchases }
$$

- Cash conversion cycle (CCC) $=\mathrm{ACP}+\mathrm{ICP}-\mathrm{APP}$

- Firm size (FS) = Natural logarithm dari total turnover (sales)

- Debt ratio (Debt) $=$ Short-term loans + long-term loans

$$
\text { Total asset }
$$

- Fixed Asset Ratio (FAR) $=\underline{\text { Fixed Asset }}$

Total Asset

- Gross Domestic Product Growth (GDPGrow) = Tingkat pertumbuhan GDP

- Umur perusahaan (Age) = Natural logarithm dari jumlah tahun komersial perusahaan

Model pengujian empirisnya adalah sebagai berikut:

a. Pengujian pengaruh Cash Conversion Cycle (CCC) terhadap kinerja $R O A_{i t}=\alpha_{0}+\beta_{1} C C C_{i t}+\beta_{2} F_{i t}+\beta_{3} D_{e b t}+\beta_{4} F_{A R} R_{i t}+\beta_{5} G D P P_{i t}+B_{6} A e_{i t}+\varepsilon_{i}$

b. Pengujian pengaruh Average Collection Period (ACP) terhadap kinerja $R O A_{i t}=\alpha_{0}+\beta_{1} A_{C P} P_{i t}+\beta_{2} F_{i t}+\beta_{3} D_{e b t}+\beta_{4} F_{A R}+\beta_{5} G D P_{i t}+B_{6} A e_{i t}+\varepsilon_{i}$

c. Pengujian pengaruh Inventory Conversion Period (ICP) terhadap kinerja $R O A_{i t}=\alpha_{0}+\beta_{1} I C P_{i t}+\beta_{2} F_{i t}+\beta_{3} D_{e b t} i t+\beta_{4} F_{A R} R_{i t}+\beta_{5} G D P_{i t}+B_{6} A e_{i t}+\varepsilon_{i}$

d. Pengujian pengaruh Average Payment Period (APP) terhadap kinerja $R O A_{i t}=\alpha_{0}+\beta_{1} A_{P P}+\beta_{2} F_{i t}+\beta_{3} D_{e b t}+\beta_{4} F_{A R} R_{i t}+\beta_{5} G D P P_{i t}+B_{6} A e_{i t}+\varepsilon_{i}$

e. Pengujian pengaruh ACP, ICP, dan APP terhadap kinerja

$$
\begin{aligned}
R O A_{i t}= & \alpha_{0}+\beta_{1} A C P_{i t}+\beta_{2} I C P_{i t}+\beta_{3} A P P_{i t}+\beta_{4} F_{i t}+\beta_{5} D e b t_{i t}+\beta_{6} F A R_{i t}+ \\
& B_{7} G D P P_{i t}+\beta_{8} A e_{i t}+\varepsilon_{i}
\end{aligned}
$$

Pengujian Pengaruh Tingkat Keagresifan Working Capital Management terhadap Kinerja Perusahaan. Sama dengan pengujian sebelumnya, variabel dependen pada pengujian ini adalah kinerja perusahaan yang diproxy-kan oleh variabel return on asset (ROA). Variabel independen yang digunakan pada pengujian ini adalah tingkat 
keagresifan WCM. Variabel ini diproxy-kan oleh variabel aggressive investing policy (AIP) dan aggressive financing policy (AFP). Pengukuran variabel-variabelnya adalah sebagai berikut:

- Aggressive Investment Policy (AIP) = $\underline{\text { Total current assets (TCA) }}$

Total Assets (TA)

- Aggressive Financing Policy (AFP) $=\underline{\text { Total current liabilities }(T C L)}$

Total Assets (TA)

Model pengujian empirisnya adalah sebagai berikut:

$R O A_{i t}=\alpha+\beta_{1}\left(T C A_{i t} / T A_{i t}\right)+\beta_{2}\left(T C L_{i t} / T A_{i t}\right)+\varepsilon_{i}$

Pengujian Pengaruh Cash Conversion Cycle terhadap Risiko Perusahaan. Variabel dependen untuk pengujian ini adalah risiko perusahaan yang di-proxy-kan oleh variabel standar deviasi dari return on asset (SDROA). Sama seperti pengujian 1 (pengaruh CCC terhadap kinerja perusahaan), variabel independen utama yang digunakan pada pengujian ini adalah CCC, sedangkan variabel independen lain yang juga diuji adalah ACP, ICP, dan APP. Variabel kontrol yang digunakan dalam pengujian ini juga sama dengan pengujian 1 , demikian pula dengan pengukuran variabelvariabelnya. Model pengujian empirisnya adalah sebagai berikut:

a. Pengujian pengaruh Cash Conversion Cycle (CCC) terhadap risiko $\mathrm{SDROA}_{i \mathrm{t}}=\alpha_{0}+\beta_{1} \mathrm{CCC}_{i \mathrm{t}}+\beta_{2} \mathrm{FS}_{i \mathrm{t}}+\beta_{3}$ Debt $_{i \mathrm{t}}+\beta_{4} \mathrm{FAR}_{\mathrm{it}}+\beta_{5} \mathrm{GDP}_{\mathrm{it}}+\mathrm{B}_{6} \mathrm{Age}_{\mathrm{it}}+\varepsilon_{\mathrm{i}}$

b. Pengujian pengaruh Average Collection Period (ACP) terhadap risiko $\mathrm{SDROA}_{i \mathrm{t}}=\alpha_{0}+\beta_{1} \mathrm{ACP}_{\mathrm{it}}+\beta_{2} \mathrm{FS}_{\mathrm{it}}+\beta_{3}$ Debt $_{\mathrm{it}}+\beta_{4} \mathrm{FAR}_{\mathrm{it}}+\beta_{5} \mathrm{GDP}_{\mathrm{it}}+\mathrm{B}_{6} \mathrm{Age}_{\mathrm{it}}+\varepsilon_{\mathrm{i}}$

c. Pengujian pengaruh Inventory Conversion Period (ICP) terhadap risiko $\mathrm{SDROA}_{i \mathrm{t}}=\alpha_{0}+\beta_{1} I C P_{i \mathrm{t}}+\beta_{2} \mathrm{FS}_{i \mathrm{t}}+\beta_{3}$ Debt $_{i \mathrm{t}}+\beta_{4} \mathrm{FAR}_{\mathrm{it}}+\beta_{5} \mathrm{GDP}_{\mathrm{it}}+\mathrm{B}_{6} \mathrm{Age}_{\mathrm{it}}+\varepsilon_{\mathrm{i}}$

d. Pengujian pengaruh Average Payment Period (APP) terhadap risiko SDROA $_{i t}=\alpha_{0}+\beta_{1}$ APP $_{i t}+\beta_{2} F_{i t}+\beta_{3}$ Debt $_{i t}+\beta_{4} F_{A R}{ }_{i t}+\beta_{5} G D P P_{i t}+B_{6} A e_{i t}+\varepsilon_{i}$

e. Pengujian SDROA ${ }_{i t}=\alpha_{0}+\beta_{1} A C P_{i t}+\beta_{2} I C P_{i t}+\beta_{3} A P P_{i t}+\beta_{4} F_{i t}+\beta_{5} D$ ebt $_{i t}+\beta_{6} F_{A R}+$ $\mathrm{B}_{7} \mathrm{GDP}_{\mathrm{it}}+\beta_{8} \mathrm{Age}_{\mathrm{it}}+\varepsilon_{\mathrm{i}}$

Pengujian Pengaruh Tingkat Keagresifan Working Capital Management terhadap Risiko Perusahaan. Sama seperti pengujian 2 (pengaruh tingkat keagresifan WCM terhadap kinerja), variabel dependen untuk pengujian ini adalah risiko perusahaan yang di-proxy-kan oleh variabel standar deviasi dari return on asset (SDROA), sedangkan variabel independenya adalah tingkat keagresifan WCM. Variabel ini diproxy-kan oleh variabel AIP dan AFP. Pengukuran variabel-variabel yang digunakan pada pengujian ini juga sama dengan yang digunakan pada pengujian sebelumnya. Model pengujian empirisnya adalah sebagai berikut:

SDROA $_{i t}=\alpha+\beta_{1}\left(\mathrm{TCA}_{\mathrm{it}} / \mathrm{TA}_{\mathrm{it}}\right)+\beta_{2}\left(\mathrm{TCL}_{\mathrm{it}} / \mathrm{TA}_{\mathrm{it}}\right)+\varepsilon_{\mathrm{i}}$

\section{Hasil Penelitian}

III.1. Pengujian Pengaruh Cash Conversion Cycle terhadap Kinerja Perusahaan

Berdasarkan teori dan pandangan tradisional serta penelitian-penelitian sebelumnya, mayoritas menunjukkan bahwa WCM memiliki pengaruh negatif terhadap kinerja perusahaan. Artinya bahwa semakin tinggi WCM yang ditunjukkan oleh siklus konversi kas yang tinggi (likuiditas yang tinggi), maka kinerja perusahaan semakin rendah (di-proxy-kan oleh ROA). Walaupun tidak demikian halnya dengan 
yang ditemukan oleh Gill, et al. (2010) yang menyatakan bahwa cash conversion cycle (CCC) berpengaruh positif terhadap profitabilitas atau kinerja perusahaan, yaitu semakin tinggi CCC maka profitabilitas semakin tinggi. Tetapi hasil pengujian secara empiris terhadap 14 perusahaan yang menjadi sampel pada tingkat signifikansi 5\% menunjukkan bahwa CCC tidak berpengaruh terhadap ROA. Dengan kata lain hipotesis 1 tidak terdukung. Hal ini menunjukkan bahwa tidak ada pengaruh antara pengelolaan modal kerja dengan profitabilitas perusahaan. Namun demikian jika dilihat dari besaran dan arah koefisien CCC yaitu -0,0000561 menunjukkan pengaruh negatif CCC terhadap ROA walaupun tidak signifikan. Artinya jika CCC meningkat sebesar 1 hari maka ROA akan menurun sebesar 0,0000561 juta rupiah atau Rp 56,1. Jadi jika hanya memperhatikan arah koefisien tanpa memperhatikan nilai t-statistis dan probabilitas, hasil penelitian ini sama dengan hasil sebagian besar penelitian sebelumnya yang memperlihatkan pengaruh negatif CCC terhadap profitabilitas dan juga sesuai dengan hipotesis yang diajukan. Hal ini dapat dijelaskan bahwa semakin tinggi CCC maka profitabilitas akan semakin rendah karena perusahaan lebih lama dalam mengkonversi asetnya dalam bentuk kas. Atau dengan kata lain, working capital management berpengaruh negatif terhadap kinerja perusahaan.

Pengujian secara terpisah untuk komponen-komponen siklus konversi kas yaitu ACP dan ICP juga menunjukkan bahwa pengelolaan modal kerja tidak mempengaruhi kinerja perusahaan, walaupun jika dilihat dari arah koefisien untuk ACP adalah negatif, dimana hal ini sesuai dengan teorinya. Namun demikian pengujian komponen siklus konversi kas yang lain yaitu APP menunjukkan pengaruhnya secara negatif dan signifikan terhadap ROA, dimana hal tersebut tidak sesuai dengan teorinya. Secara keseluruhan, tiga dari empat komponen WCM menunjukkan pengaruh yang negatif terhadap kinerja perusahaan, walaupun tidak seluruhnya signifikan. Dengan demikian hasil tersebut menunjukkan terdapat trade off antara likuiditas dan profitabilitas. Tidak signifikannya pengaruh CCC terhadap kinerja perusahaan dapat disebabkan oleh sampel perusahaan yang sangat terbatas dan periode observasi yang relatif pendek. Faktor lainnya yaitu adanya variasi antar perusahaan dalam hal jenis perusahaan, jumlah aset, kewajiban, penjualan, serta kebijakan kredit. Dengan demikian hasil penelitian ini tidak bisa digeneralisasi untuk semua perusahaan. Hasil pengujian secara lebih jelas dapat dilihat pada Tabel 1.

\section{III.2. Pengujian Pengaruh Tingkat Keagresifan Working Capital Management terhadap} Kinerja Perusahaan

Pengelolaan modal kerja yang dilakukan oleh setiap perusahaan adalah berbedabeda. Perbedaan tingkat keagresifan WCM tersebut diduga dapat menyebabkan perbedaan dalam tingkat profitabilitas. Tingkat keagresifan WCM dapat dilihat dari variabel aggressive investing policy (AIP) dan aggressive financing policy (AFP). Kebijakan investasi yang agresif menghasilkan investasi pada aset lancar yang minimal dibandingkan dengan aset tetapnya. Sebaliknya, kebijakan investasi yang konservatif menempatkan lebih banyak investasi pada aset lancar dengan opportunity cost yang mungkin terjadi yaitu berkurangnya profitabilitas (kinerja). Jika proporsi aset lancar dibandingkan total aset meningkat, perusahaan dikatakan konservatif dalam mengelola aset lancar perusahaan. Kondisi yang sebaliknya adalah kebijakan WCM 
yang agresif. Jadi semakin rendah nilai AIP, maka kebijakan working capital-nya dikatakan semakin agresif. Di lain pihak, kebijakan pendanaan (financing) yang agresif menggunakan kewajiban lancar yang lebih tinggi dan kewajiban jangka panjang serta capital yang lebih rendah, di mana kebijakan pendanaan yang agresif ini dapat meningkatkan profitabilitas. Sebaliknya, kebijakan pendanaan yang konservatif menggunakan kewajiban lancar yang lebih rendah dan kewajiban jangka panjang serta capital yang lebih tinggi. Jadi semakin tinggi nilai AFP, maka kebijakan working capitalnya dikatakan semakin agresif.

Berdasarkan hasil perhitungan dengan tingkat signifikansi $5 \%$ menunjukkan bahwa secara umum 14 perusahaan sampel melakukan kebijakan WCM-nya secara relatif agresif untuk kebijakan investasi, tetapi relatif konservatif untuk kebijakan pendanaan. Hal ini terlihat dari nilai AIP dan AFP yang relatif rendah, yaitu masing-masing sebesar 0,361 dan 0,251. Hasil regresi dari 14 perusahaan selama tiga tahun menunjukkan bahwa AIP dan AFP berpengaruh secara signifikan terhadap ROA, tetapi pengaruhnya berbeda. AIP berpengaruh secara positif terhadap ROA (dengan koefisien regresi sebesar 0.493) sedangkan AFP berpengaruh secara negatif terhadap ROA (dengan koefisien regresi sebesar -0,574). Atau dengan kata lain working capital management memengaruhi kinerja perusahaan. Dengan demikian hasil penelitian ini mendukung hipotesis 2 secara parsial karena arahnya berbeda antara kebijakan investasi (AIP) dan kebijakan pendanaan (AFP). Jadi yang lebih sesuai dengan hipotesis adalah kebijakan investasi yang relatif agresif yaitu berpengaruh positif terhadap kinerja perusahaan.

Jika merujuk pada penelitian sebelumnya, walaupun secara umum menunjukkan bahwa kebijakan pengelolaan modal kerja yang agresif dapat meningkatkan profitabilitas perusahaan, tetapi ada juga penelitian yang menunjukkan hasil sebaliknya, di antaranya adalah penelitian Nazir dan Afza (2009) yang menyatakan bahwa kebijakan yang konservatiflah yang lebih memberikan nilai pada perusahaan. Dengan demikian tidak sepenuhnya perusahaan yang memiliki kebijakan pengelolaan modal kerja yang agresif berpotensi untuk mendapatkan tingkat profitabilitas yang tinggi. Perlu dilakukan penelitian dengan sampel yang lebih banyak untuk mendapatkan hasil yang lebih konsisten. Namun demikian, untuk mencapai tingkat profitabilitas yang tinggi, perusahaan tetap perlu memerhatikan pengelolaan modal kerjanya, baik kebijakan investasi maupun kebijakan pendanaan, dengan tetap memperhatikan tingkat likuiditasnya jangan sampai terlalu rendah. Hasil pengujian secara lebih jelas dapat dilihat pada Tabel 1.

\section{III.3. Pengujian Pengaruh Cash Conversion Cycle terhadap Risiko Perusahaan}

Pengujian hipotesis yang ketiga ini menggunakan variabel independen yang sama dengan pengujian hipotesis yang pertama kecuali variabel dependennya, yaitu risiko perusahaan. Selain melihat pengaruh CCC dan komponen-komponen WCM lain (ACP, ICP, dan APP) terhadap kinerja, penting juga mengetahui pengaruhnya terhadap risiko. Risiko perusahaan yang diuji pada penelitian ini yaitu standar deviasi dari tingkat profitabilitas (standar deviasi dari ROA). Pada umumnya untuk tingkat return tertentu akan menghadapi risiko dengan tingkatan yang sama. Oleh karena itu pada pengujian ini dihipotesiskan pengaruh cash conversion cycle terhadap risiko dengan arah yang sama seperti pengaruh cash conversion cycle terhadap kinerja, yaitu berpengaruh 
negatif. Akan tetapi, hampir sama seperti hipotesis 1, pada tingkat signifikansi 5\% hasil pengujian 14 sampel perusahaan menunjukkan bahwa cash conversion cycle tidak berpengaruh signifikan terhadap risiko perusahaan. Dengan demikian hipotesis 3 tidak terdukung pada penelitian ini.

Jika regresi dilakukan secara terpisah untuk komponen-komponen working capital management yang lain yaitu ACP dan ICP juga tidak memengaruhi risiko perusahaan secara signifikan, walaupun untuk variabel ACP arah koefisiennya adalah negatif yaitu 4,20E-18 (sesuai dengan teori). Jadi semakin tinggi average collection period perusahaan, maka risikonya akan semakin rendah. Di sisi lain, variabel APP mempengaruhi risiko perusahaan secara positif yaitu sebesar $8,73 \mathrm{E}-16$ dan hal ini sesuai dengan teori dan mayoritas penelitian-penelitian sebelumnya. Artinya semakin lama perusahaan membayar kepada kreditor atau supplier maka kinerja dan risiko perusahaan akan semakin tinggi. Hasil pengujian secara lebih jelas dapat dilihat pada Tabel 1. Secara keseluruhan, sebagian komponen working capital management sesuai dengan teori dan hasil penelitian sebelumnya, dan sebagian lagi tidak. Kuat dugaan hal ini disebabkan oleh sampel perusahaan dan perioda penelitian yang sangat terbatas.

4. Pengujian Pengaruh Tingkat Keagresifan Working Capital Management terhadap Risiko Perusahaan

Variabel-variabel independen pada pengujian hipotesis ke-4 ini sama seperti hipotesis ke-2 yaitu AIP dan AFP, yang membedakan adalah variabel dependennya yaitu risiko perusahaan yang di-proxy-kan oleh standar deviasi dari ROA. Hasil pengujian dari regresi terhadap 14 sampel perusahaan selama tiga tahun dengan tingkat signifikansi 5\% menunjukkan bahwa tingkat keagresifan WCM dari sisi kebijakan investasi (AIP) berpengaruh secara positif dan signifikan terhadap risiko perusahaan, yang ditunjukkan dengan nilai koefisiennya sebesar 4,87E-16 dan nilai probabilitas sebesar 0,0001 . Artinya semakin agresif perusahaan dalam melakukan kebijakan investasinya, maka kinerjanya akan semakin tinggi dan risiko perusahaannya pun akan semakin tinggi. Namun jika dilihat dari sisi kebijakan pendanaan (AFP), tingkat keagresifan WCM tidak berpengaruh terhadap risiko perusahaan yang ditunjukkan oleh nilai probabilitas yang tinggi yaitu 0,6625 (lebih besar dari 5\%). Dengan demikian hasil penelitian ini mendukung hipotesis 4 secara parsial, yaitu hanya untuk kebijakan investasi saja. Hasil pengujian secara lebih jelas dapat dilihat pada Tabel 1.

Tabel 1. Hasil Pengujian

\begin{tabular}{ccccccc}
\hline No & Pengujian & $\begin{array}{c}\text { Variabel } \\
\text { Dependen }\end{array}$ & $\begin{array}{c}\text { Variabel } \\
\text { Independen }\end{array}$ & Koefisien & t-statistik & Probability \\
\hline 1 & Pengujian 1a & ROA & CCC & $-5.61 \mathrm{E}-05$ & -0.125340 & 0.9010 \\
2 & Pengujian 1b & ROA & ACP & -0.001245 & -0.957332 & 0.3450 \\
3 & Pengujian 1c & ROA & ICP & 0.000151 & 0.255279 & 0.8000 \\
4 & Pengujian 1d & ROA & APP & -0.492017 & -2.812296 & 0.0080 \\
5 & Pengujian 1e & ROA & ACP & -0.001088 & -0.839812 & 0.4071 \\
& & & ICP & 0.000175 & 0.301381 & 0.7650 \\
& & \multirow{2}{*}{ ROA } & APP & -0.472269 & -2.615027 & 0.0133 \\
6 & Pengujian 2 & AIP & 0.493312 & 3.432680 & 0.0014 \\
& & & AFP & -0.574112 & -3.432930 & 0.0014 \\
7 & Pengujian 3a & SDROA & CCC & 0.000000 & 0.000000 & 1.0000
\end{tabular}




\begin{tabular}{cccccrr}
\hline No & Pengujian & $\begin{array}{c}\text { Variabel } \\
\text { Dependen }\end{array}$ & $\begin{array}{c}\text { Variabel } \\
\text { Independen }\end{array}$ & Koefisien & t-statistik & Probability \\
\hline 8 & Pengujian 3b & SDROA & ACP & $-4.20 \mathrm{E}-18$ & -0.627841 & 0.5342 \\
9 & Pengujian 3c & SDROA & ICP & $3.22 \mathrm{E}-18$ & 1.064667 & 0.2943 \\
10 & Pengujian 3d & SDROA & APP & $8.73 \mathrm{E}-16$ & 3.346330 & 0.0020 \\
\hline 11 & Pengujian 3e & SDROA & ACP & $-1.01 \mathrm{E}-17$ & -1.218908 & 0.2315 \\
& & & ICP & $6.32 \mathrm{E}-18$ & 1.699105 & 0.0987 \\
& & & APP & $4.45 \mathrm{E}-15$ & 3.862209 & 0.0005 \\
12 & \multirow{2}{*}{ Pengujian 4 } & SDROA & AIP & $4.87 \mathrm{E}-16$ & 4.413732 & 0.0001 \\
& & & AFP & $-5.64 \mathrm{E}-17$ & -0.439768 & 0.6625 \\
\hline
\end{tabular}

\section{Kesimpulan}

Working capital management yang ditunjukkan oleh cash conversion cycle tidak terlihat berpengaruh secara signifikan terhadap profitabilitas atau kinerja perusahaan dan juga risiko perusahaan. Walaupun jika tidak melihat signifikansinya, arahnya adalah sesuai dengan hipotesis bahwa cash conversion cycle mempengaruhi kinerja perusahaan secara negatif. Namun demikian, salah satu komponen working capital management yang lain yaitu average payment period memiliki pengaruh signifikan terhadap profitabilitas dan risiko perusahaan.

Begitu juga halnya dengan tingkat keagresifan working capital management yang dilihat dari kebijakan investasi dan kebijakan pendanaan memiliki pengaruh signifikan terhadap profitabilitas perusahaan.

Untuk risiko perusahaan, yang mempengaruhi secara signifikan hanyalah kebijakan investasi saja. Namun demikian, tingkat keagresifan working capital management yang lebih sesuai dengan hipotesis yang diajukan adalah kebijakan investasi, yaitu semakin agresif kebijakan investasi yang dilakukan perusahaan, maka kinerja dan risikonya akan semakin tinggi.

\section{Daftar Pustaka}

Dong, H.P., J. Su, J. 2010. The relation between working capital management and profitability : A Vietnam Case, Journal of Finance and Economics, 49(2010), 62-71.

Gill, A., N. Biger, N. Mathur. 2010. The relation between working capital management and profitability: Evidence from The United States, Business and Economics Journal, Vol 2010: BEJ-10, 1-9.

Keown, A.J., D.F. Scott, J.D. Martin, J.W. Petty. 2001. Fundamental of Financial management, Pearson Education Asia Pte. Ltd.

Mathuva, D.M. 2010. The influence of working capital management components on corporate profitability : A survey on Kenyan Listed Firms, Journal of Business Management, 4(1), 1-11.

Nazir, M. dan T. Afza. 2009. Impact of Aggressive Working Capital Management Policy on Firm's Profitability, Journal of Applied Finance, Vol. 15, No. 8, 19-30.

Raheman, A., M. Nasr. 2007. Working capital management and profitability - Case of Pakistani firms, Business Research Papers, Vol. 3, No.1, 279-300. 
12 | Ermawati - Pengaruh Working Capital

Sen, M., E. Oruc. 2009. Relationship Between Efficiency Level of Working Capital Management and Return on Total Assets in Istanbul Stock Exchange (Ise), International Journal of Business and Management, Vol. 4, No. 10, 109-114.

Weinraub, H.J., S. Visscher. 1998. Industry practice relating to aggressive conservative working capital policies, Journal of Financial and Strategic Decisions, Vol. 11, No. 2, 11-18.

Zariyawati, M.A., M.N. Annuar, H. Taufiq, A.S.A. Rahim. 2009. Working capital management and corporate performance : Case of Malaysia, Journal of Modern Accounting and Auditing, Vol. 5, No. 11, 47-54. 